\title{
THE PRESENCE OF POTENTIALLY TOXIGENIC FUNGI IN POULTRY FEED **
}

\author{
V. Krnjaja*, Lj. Stojanović, R. Cmiljanić, S. Trenkovski, D. \\ Tomašević ${ }^{1}$ \\ ${ }^{1}$ Institute for Animal Husbandry, Belgrade-Zemun, 11080 Zemun \\ * Corresponding author: VesnaKrnjaja.IZS@gmail.com \\ ** Original scientific paper - Originalni naučni rad \\ Research was financed by the Ministry of Science and Technological Development of Republic of \\ Serbia within projects TR-20046 and TR-20021 - Rad je finansiran od strane Ministarstva za \\ nauku i tehnološki razvoj Republike Srbije u okviru projekata TR-20046 i TR-20021
}

\begin{abstract}
In Serbia, commercial feedstuffs are an important component in modern animal husbandry, but there is no information available about fungal contaminataion. Because of that the aim of this study was to determine the mycoflora incidence in poultry feeds. A total of 230 samples of poultry feeds were examined for total fungi count and the presence of potential toxigenic fungi genera. Total fungi count were $1-9 \times 10^{4} \mathrm{CFU} \mathrm{g}^{-1}$ in the most of investigated poultry feed samples $(38.26 \%)$. The most prevalent fungi genera were Fusarium (56.09\%) and Aspergillus (54.35\%), followed by Rhizopus (40\%), Penicillium (30.87\%), Mucor (30.04\%) and the least frequency species were from genus Alternaria (3.48\%).
\end{abstract}

Key words: poultry feed, total fungi count, toxigenic fungi genera.

\section{Introduction}

The presence of mould (fungi) and mycotoxins in poultry feeds from the raw material used in their production. Mould and mycotoxins contamination of the raw materials occur during the pre-harvest (field produced fungi) and/or the post-harvest (storage-produced fungi) periods. During these periods, temperature and humidity play an important role in the growth of fungi and mycotoxins contamination.

The intake of very low levels of mycotoxins causes overt mycotoxicosis but also leads to the impairment of immune and acquired resistance to infections causing health problems which lead to economic losses in the form of decreased productivity (Dalcero et al., 1998). Mycotoxicosis can be with fatal 
consequences in form of direct losses due to animal mortality. Of numerous mycotoxins, most attention in the world is directed to aflatoxins, ochratoxins, zearalenones, toxins from the group of trichothecenes and fumonisins. Aflatoxins are the most spread, most dangerous and most studied mycotoxins. Main producers of these mycotoxins are fungi of genus Aspergillus, although also some other species of fungi from genera Penicillium and Rhizopus produce them. Zearalenone (ZEA) is metabolite of some species of fungi from genus Fusarium. Trihothecenes are produced by different fungi species belonging to different genera, such as: Trichothecium, Stachybotrys, Myrothecium, Cephalosporium, Trichoderma, Penicillium, Fusarium, etc. Among fungi which produce trihothecenes, the most important are certain species of genus Fusarium. The fumonisins are a group of economically important mycotoxins and very common contaminants of maize-based foods and feeds throughout the world. The major producers of fumonisins are Fusarium verticillioides and closely related species (Muntañola-Cvetković, 1990; Jurić and Pupavac, 1996; Fandohan et al., 2003).

Pathogenic micro organisms and their secondary metabolites (mycotoxins) in general chain of nutrition represent the most important potential risk to animal and human health. Because of the harmful effect of mycotoxins in chain of nutrition of humans and animals, in this paper, total fungi count and presence of potentially toxigenic fungi in samples of poultry feed was determined.

\section{Material and methods}

A total 230 samples of feed intended for nutrition of poultry of all categories were investigated for determination of total fungi count and presence potentially toxigenic genera of fungi. Samples were investigated during 2007 in accredited microbiological laboratory of the Institute for Animal Husbandry, Belgrade-Zemun, and originate from the territory of the Republic of Serbia. Investigation of total fungi count was done using standard microbiological methods according to valid regulations on hygiene standard and quality of animal feed. Isolation of special fungi genera was done by planting of samples on selective foundation for fungi, Sabouraud dextrose agar.

Based on macroscopic and microscopic characteristics of pure cultures of obtained isolates from analyzed poultry feed samples fungi genera were identified according to methods of Mihajlović (1983), Nelson et al. (1983), Burgess et al. (1994) and Watanabe (1994). 


\section{Results and discussion}

Total fungi count is one of the criteria in evaluation of hygienic quality and it is very important for orientation in lower or higher probability that the feed contains mycotoxins. According to conditions defined in Articles 8 and 9 of the Regulation on maximal quantities of harmful substances and components in livestock feed (Official Journal of SRY 2/90), mixtures and raw materials for animal feed are not in compliance with standards of the hygiene quality if they contain above $300.000 \mathrm{CFU} \mathrm{g}^{-1}$ of forage mixture for older animal categories or $50.000 \mathrm{CFU} \mathrm{g}^{-1}$ for younger animals.

By analysis of investigated poultry feed samples from 0 to $6 \times 10^{5} \mathrm{CFU}$ $\mathrm{g}^{-1}$ was established. Majority of samples analyzed contained 1-9 x $10^{4} \mathrm{CFU} \mathrm{g}^{-1}$ $(38.26 \%)$. Relative high percent $(18.70 \%)$ of investigated poultry feed samples were without contamination of fungi (table 1).

Table 1. Level of contamination of investigated samples of poultry feed with fungi Tabela 1. Stepen kontaminacije ispitivanih uzoraka hrane za živinu gljivama

\begin{tabular}{|c|c|c|}
\hline Fungal counts $\left(\mathrm{CFU} \mathrm{g}^{-1} *\right)$ & Number of samples & Frequency (\%) \\
\hline $1-6 \times 10^{5}$ & $230 / 23$ & 10 \\
\hline $1-9 \times 10^{4}$ & $230 / 88$ & 38.26 \\
\hline $1-9 \times 10^{3}$ & $230 / 63$ & 27.39 \\
\hline$<1 \times 10^{3}$ & $230 / 13$ & 5.65 \\
\hline 0 & $230 / 43$ & 18.70 \\
\hline
\end{tabular}

*Colony forming units per $g$ of sample

By applying defined criteria (Official journal of SRY 2/90) on 230 samples of poultry feed collected in 2007 , it was established that $14.78 \%$ of feed samples for young category of poultry wasn't microbiologically correct and $2.61 \%$ of feed samples for older category of poultry, whereas $82.61 \%$ of feed samples for both stated categories of poultry did satisfy standards of microbiological adequacy (table 2).

By microbiological analysis of investigated poultry feed samples, six fungi genera have been isolated and identified: Fusarium, Aspergillus, Rhizopus, Penicillium, Mucor and Alternaria. Considering average values of their presence in percentage in all investigated poultry feed samples the most present were fungi species from genera Fusarium (56.09\%) and Aspergillus (54.35\%), followed by Rhizopus (40\%), Penicillium (30.87\%), Mucor (30.04\%) and Alternaria (3.48\%). In most of the samples more than one fungi genus were identified. 
Table 2. Number and percentage of investigated poultry feed samples with total fungi count within limit values according to Regulation

Tabela 2. Broj i procenat ispitivanih uzoraka hrane za živinu sa ukupnim brojem gljiva na graničnom broju prema Pravilniku

\begin{tabular}{|l|c|c|}
\hline${\text { Fungal counts }\left(\mathrm{CFU} \mathrm{g}^{-1} *\right)}^{-1}$ Number of samples & Frequency $(\%)$ \\
\hline$>50.000^{\mathrm{a}}$ & $230 / 34$ & 14.78 \\
\hline$>300.000^{\mathrm{b}}$ & $230 / 6$ & 2.61 \\
\hline Bellow limiting values $^{\mathrm{c}}$ & $230 / 190$ & 82.61 \\
\hline
\end{tabular}

*Colony forming units per $\mathrm{g}$ of sample

a - value of CFU $\mathrm{g}^{-1}$ which is not in compliance with conditions determined in Regulation for young categories of animals

${ }^{b}$ - value of CFU $\mathrm{g}^{-1}$ which is not in compliance with conditions determined in Regulation for older categories of animals

${ }^{c}$ - value of $\mathrm{CFU} \mathrm{g} \mathrm{g}^{-1}$ which is in compliance with conditions determined in Regulation for both categories of animals

Šefer et al. (1998) established that of 160 analyzed samples of forage mixtures used in poultry nutrition only 57 (35.6\%) were in accordance with provisions of the Regulation on quality of livestock feed, and in mixtures for grown animals maximum $3 \times 10^{6} \mathrm{CFU} \mathrm{g}{ }^{-1}$ was established. The most frequent isolated fungi species are of Mucor $(76.5 \%)$ genus, followed by species of genera Aspergillus (58.3\%), Penicillium (29.6\%) and Fusarium (15.6\%). All investigated mixtures were contaminated with two mycotoxins zearalenone and ochratoxin (Šefer et al., 1998).

According to data obtained by Jurić and Pupavac (1996), in their investigation of contamination of different types of feed mixtures and their components, the most frequent contamination is with ochratoxins, zearalenones and aflatoxins produced by fungi from genera Aspergillus, Fusarium and Penicillium.

Table 3. Frequency in percentage of fungi genera in investigation poultry feed samples.

Tabela 3. Procentualna zastupljenost rodova gljiva u ispitivanim uzorcima hrane za živinu.

\begin{tabular}{|l|c|}
\hline Fungal genera & Frequency (\%) \\
\hline Alternaria & 3.48 \\
\hline Aspergillus & 54.35 \\
\hline Fusarium & 56.09 \\
\hline Mucor & 30.04 \\
\hline Penicillium & 30.87 \\
\hline Rhizopus & 40 \\
\hline
\end{tabular}

In Argentina, the species belonging to Aspergillus (85\%) and Fusarium (70\%) genera were the most frequent in 130 investigated poultry feed samples and fungal counts ranged from $6.6 \times 10^{3}$ to $6.3 \times 10^{5} \mathrm{CFU} \mathrm{g}^{-1}$ (Dalcero et al., 1998). Results of Oliveira et al. (2006) showed that fungal counts in poultry 
feed samples were $2.18-3.27 \times 10^{3} \mathrm{CFU} \mathrm{g}^{-1}$. Penicillium spp. (41.26\%) and Aspergillus spp. (33.33\%) had the highest isolation frequencies followed by Fusarium spp. (20.63\%). Fumonisin $\left(\mathrm{FB}_{1}\right)$ was the most frequent $(97.8 \%)$ followed by ZEA $(77.1 \%)$ and aflatoxin $\left(\mathrm{AFB}_{1}\right)(66.7 \%)$. $\mathrm{FB}_{1}$ and $\mathrm{AFB}_{1}$ cooccurred in $64.5 \%$ of the samples tested (Oliveira et al. 2006). In Nigeria, according to data Oscho et al. (2007) of the 50 investigated poultry feed samples no was found completely free from fungi contaminant and the highest frequency of occurrence had Rhizopus spp. (44\%), followed by Fusarium spp. (42\%), Aspergillus flavus (40\%) and A. niger (38\%).

The mould spore plate count often has been used to estimate the potential risk that feed may pose to poultry health. This measurement, however, was found to be highly variable between batches of feed manufactured at different geographical locations. However, this test can be less expensive than analyses for mycotoxin contamination, while yielding a number corresponding to the number of viable mould spores per unit of feedstuff (Brothers and Wyatt, 2000). In general the fungal propagules are a helpful indicator to determine feeds'hygienic quality, these counts should not exceed the values of $1 \times 10^{5}$ CFU g ${ }^{-1}$ (Dalcero et al., 1998). Based on obtained results, sole determination of total fungi count is insufficient to estimate the quality of poultry feed. Identification of fungi genera indicates potential presence of mycotoxins, therefore for complete analysis of poultry feed it is necessary to determine also the content of mycotoxins.

\section{Conclusions}

Feeds and feedstuffs are excellent media for the growth of fungi and so, very high standard of hygiene is necessary to avoid feed contamination. One of the best ways to control feed contamination and mycotoxin problem is to investigate potentially toxigenic fungal population in feeds. Based on our mycological analyses of samples of poultry feeds the following can be concluded:

By application of standard microbiological methods in analysis of 230 poultry feed samples it was established that $2.61 \%$ of samples for older categories of poultry and $14.78 \%$ of samples for young categories of poultry are not in accordance with regulated conditions relating to correctness of livestock feed.

In investigated samples of poultry feed six fungi genera have been isolated and identified, Fusarium, Aspergillus, Rhizopus, Penicillium, Mucor and Alternaria of which genera Fusarium and Aspergillus had the highest 
presence (56.09\%) and (54.35\%) respectively, and genus Alternaria the lowest (3.481\%).

It must be pointed out that fungi species from genera Fusarium and Aspergillus are the most frequent producers of different and very dangerous mycotoxins (zearalenones, trihothecenes, fumonisins, aflatoxins, ochratoxins) in poultry feed.

Although in stated results relatively low percentage of samples with prohibited number of fungi was established, frequency of fungi genera which are significant producers of mycotoxins is not negligible/minor. Due to this fact, regular microbiological but also mycotoxicological analysis should be necessary methods for determination of quality and safety of poultry feed.

\title{
Prisustvo potencijalno toksigenih gljiva u hrani za živinu
}

\author{
V. Krnjaja, Lj. Stojanović, R. Cmiljanić, S. Trenkovski, D. Tomašević
}

\section{Rezime}

U Srbiji komercijalna hrana za životinje je važna komponenta u savremenom stočarstvu, ali nema dostupnih informacija o kontaminiranosti ove hrane gljivama. Zbog toga cilj ovoga rada je bio određivanje sastava mikoflore u hrani za živinu. U ukupno 230 uzoraka hrane za živinu proučavani su ukupan broj gljiva i prisustvo potencijalno toksigenih rodova gljiva. U većini proučavanih uzoraka hrane za živinu (38.26\%) ukupan broj gljiva bio je od 1-9 x $10^{4} \mathrm{CFU} \mathrm{g} \mathrm{g}^{-1}$. Najzastupljeniji rodovi gljiva bili su Fusarium $(56.09 \%) \mathrm{i}$ Aspergillus (54.35\%), zatim slede Rhizopus (40\%), Penicillium (30.87\%), Mucor (30.04\%) a najmanje zastupljene vrste gljiva bile su iz roda Alternaria $(3.48 \%)$. gljiva.

Ključne reči: hrana za živinu, ukupan broj gljiva, toksigeni rodovi 


\section{References}

BROTHERS, A.M., WYATT, R.D. (200): Factors influencing the mold spore plate count of poultry feed. J. Appl. Poultry Res. 9, 433-441.

BURGESS, L.W., SUMEMERELL, B.A., BULLOCK, S., GOTT, K.P., BACKHOUSE, D. (1994): Laboratory Manual for Fusarium Research. Fusarium Research Laboratory, Department of Crop Sciences, University of Sydney and Royal Botanic Gardens, Sydney, pp. 133.

DALCERO, A., MAGNOLI, C., LUNA, M., ANCASI, G., REYNOSO, M.M., CHIACCHIERA, S., MIAZZO, R., PALACIO, G. (1998): Mycoflora and naturally occuring mycotoxins in poultry feeds in Argentina. Mycopathologia $141,37-43$.

FANDOHAN, P., HELL, K., MARASAS, W.F.O., WINGFIELD, M.J. (2003): Infection of maize by Fusarium species and contamination with fumonisin in Africa. African Journal of Biotechnology, Vol 2 (12), 570-579.

JURIĆ, V., PUPAVAC, V. (1996): Mikotoksini kao indikatori kvaliteta stočne hrane. Biotehnologija u stočarstvu, 12, (1-2), 161-168.

MIHAJLOVIĆ, B. 1983. Priručnik za identifikaciju bakterija, kvasaca i plesni. Savez veterinara i veterinarskih tehničara Jugoslavije - Odbor za izdavačku delatnost, Beograd, pp. 344.

MUNTAÑOLA-CVETKOVIĆ, M. (1990): Opšta mikologija. Naučna knjiga, Beograd. p. 320.

NELSON, P.E., TOUSSOUN, T.A., MARASAS, W.F.O. (1983): Fusarium Species, an Illustrated Manual for Identification. The Pennsylvania State University Press, University Park and London, pp. 133.

OFFICIAL JOURNAL OF SRY 2/90 / SL. LIST SRJ (1990): Pravilnik o maksimalnim količinama štetnih materija i sastojaka u stočnoj hrani. No. 2.

OSHO, I.B., AWONIYI, T.A.M., ADEBAYO, A.I. (2007): Mycological investigation of compounded poultry feeds used in poultry farms in southwest Nigeria. African Journal of Biotechnology Vol. 6 (15), 1833-1836.

ŠEFER, D., JOVANOVIĆ, N., MARKOVIĆ, R., KRNJAJIĆ, D., NEDELJKOVIĆ-TRAILOVIĆ, J., SINOVEC Z. (1998): Pregled kvaliteta krmnih smeša za ishranu živine. Veterinarski glasnik 52 (7-8), 425-435.

WATANABE, T. (1994): Pictorial atlas of soil and seed fungi. In: Morphologies of cultured fungi and key to species. Lewis Publishers, Boca Raton, Boston, London, Washington D.C., pp. 410. 